\title{
Effect of niobium addition on the properties and microstructure of a high chromium cast iron alloy
} Ismael Nogueira Rabelo de Melo ${ }^{1}$, Anderson Edson da Silva ${ }^{2}$,
Leonardo Roberto da Silva ${ }^{2}$, Ivete Peixoto Pinheiro ${ }^{2}$

\footnotetext{
${ }^{1}$ Federal Institute of Minas Gerais, Ibirité, MG, Brazil.

${ }^{2}$ Materials Engineering Department, Federal Center for Technological Education of Minas Gerais, Belo Horizonte, MG, Brazil.

e-mail: ismaelnrmelo@gmail.com, anderson_edson@hotmail.com, leonardo.robertosilva@ hotmail.com, ivetepinheiro@ cefetmg.br
}

\begin{abstract}
High chromium cast iron (HCCI) is usually employed in equipment that experience high abrasive wear and therefore requires high resistance. Niobium could be added to these alloys to improve their resistance to wear. This study consisted in addressing the influence of $0.5 \%$ and $1.0 \%$ of niobium on the microstructure of a $26 \%$ $\mathrm{Cr}$ and $2.8 \% \mathrm{C} \mathrm{HCCI}$ alloy. Standard samples - without niobium - and samples with $0.5 \%$ and $1.0 \% \mathrm{Nb}$ were melted, cut and then machined into adequate dimensions for tests. Two groups of samples - with and without heat treatment - were analyzed through X-ray Diffraction (XRD), optical microscopy, scanning electron microscopy (SEM), Vickers and Rockwell-C hardness. Carbides Volume Fraction (CVF) was quantified in the heat-treated samples. The majority of $\mathrm{NbC}$ carbides were observed to be thin and presented a hook shaped morphology. In addition, it was noted a precipitation of Nb-rich layers around the $\mathrm{M}_{7} \mathrm{C}_{3}$ carbides, which could act as a higher hardness coating. There was significant reduction in carbide volume fraction, from an initial $33.3 \%$ to $28.1 \%$ for the $0.5 \% \mathrm{Nb}$ alloy, and further reduction to $24.9 \%$ for the $1.0 \% \mathrm{Nb}$ alloy, it was also noted an alteration on the quasi-eutectic microstructure to a hypoeutectic microstructure. The NbC carbides prevented hardness reduction as a result of lowering the CVF in heat-treated alloys; however, the alloys without heat treatment experienced reductions in hardness.
\end{abstract}

Keywords: Heat treatment, niobium, high chromium cast iron, microstructure.

\section{INTRODUCTION}

High chromium cast iron (HCCI) has many applications, especially in mining industry, for manufacturing components that require high resistance to abrasive wear. In contrast, for applications regarding impact, the use of HCCI is narrow due to its low impact resistance [1,2]. The high resistance to wear is mainly attributed to the presence of primary and/or eutectic carbides of the $(\mathrm{Fe}, \mathrm{Cr})_{7} \mathrm{C}_{3}$ type in a predominantly austenitic or martensitic matrix [1-3].

The wear properties of the material is influenced by factors such as size, shape and distribution of carbides, heat treatment, presence of alloys elements and retained austenite content [1-3].

HCCI exhibits hypoeutectic, eutectic and hypereutectic microstructures. The hypoeutectic alloys, in its as-cast state, displayed austenitic dendrites involved by a eutectic made of austenite and $\mathrm{M}_{7} \mathrm{C}_{3}$ carbides. The eutectic alloys showed a lamellar structure, which was formed by the eutectic. At last, the hypereutectic alloys exhibited large hexagonal primary carbides involved by the eutectic [1-3].

The hypoeutectic alloys have smaller CVF, with carbide content usually below $30 \%$. The eutectic alloy results in CVF around $30 \%$, while the hypereutectic alloys usually present carbide contents above that value. The literature indicates that, in general, the eutectic microstructure results in a higher resistance to abrasive wear [1-3].

Zum Gahr and Eldis [3] analyzed HCCI alloys hardness as a function of their CVF. The referred study 
showed that HCCI hardness is directly proportional to CVF in both austenitic and martensitic matrixes.

Niobium can be added in cast iron production, mainly to increase resistance to wear [4-10].

The resistance to abrasion of alloys containing niobium has been associated to the presence of $\mathrm{NbC}$ metallic carbides, which resist the abrasive penetration, due to the high hardness of these carbides [4-7, 9,10].

The distribution and morphology of niobium carbides should be controlled to optimize mechanical properties in the final product, since neither coarse nor agglomerated carbides are desired on the microstructure [11].

Controlled additions of niobium in HCCI alloys reduce the volume fraction of primary and/or eutectic carbides, which makes it possible for an alloy with 'initial' chemical composition of hypereutectic to result in a eutectic alloy $[6-8,12]$. These alloys exhibit $\mathrm{NbC}$ and showed higher resistance to abrasion when compared to alloys that did not experienced niobium addition 13 . Values between $0.5 \%$ and $1.0 \%$ for addition showed significant gains regarding the benefit-cost ratio [13].

This study aims to assess the influence of $0.5 \%$ and $1.0 \%$ additions of niobium on the microstructure, morphology and carbide volume fraction; thus, the influence of these variables in micro-hardness and hardness of a $26 \% \mathrm{Cr}$ and $2.8 \% \mathrm{C} \mathrm{HCCI}$ alloy.

\section{Materials and methods}

The raw materials were composed by pieces from HCCI rotor and additions of niobium were performed under $1550^{\circ} \mathrm{C} \pm 50^{\circ} \mathrm{C}$ with scraps of a Fe-Nb alloy with a $66 \% \mathrm{Nb}$ content, which presented an average particle size of $19.73 \mu \mathrm{m}$. The melting was performed in a medium-frequency induction furnace from Inductotherm with $25 \mathrm{Kg}$ of capacity.

Three alloys were melted according to previously verified ASTM A-532 Class III type A, and their corresponding chemical compositions after melting can be observed in Table 1.

Table 1: Alloys chemical compositions (\%)

\begin{tabular}{lcccccccccc}
\hline \multicolumn{1}{c}{ ALLOY } & Cr & C & Nb & Mn & Si & Ni & Mo & Cu & P & S \\
\hline HCCI $(0 \% \mathrm{Nb})$ & 26.626 & 2.892 & 0.063 & 1.622 & 0.572 & 0.519 & 0.027 & 0.088 & 0.032 & 0.006 \\
HCCI $(0.5 \% \mathrm{Nb})$ & 26.172 & 2.844 & 0.476 & 1.405 & 0.566 & 0.498 & 0.025 & 0.098 & 0.032 & 0.007 \\
HCCI $(1 \% \mathrm{Nb})$ & 25.954 & 2.743 & 1.014 & 1.216 & 0.460 & 0.488 & 0.025 & 0.106 & 0.034 & 0.007 \\
\hline
\end{tabular}

The samples at $1585^{\circ} \mathrm{C} \pm 15^{\circ} \mathrm{C}$ were poured into green sand molds of $75 \times 25 \times 12.7 \mathrm{~mm}$ dimensions [14]. Only the underneath surfaces of the samples were analyzed. A portion of the samples was heat-treated by annealing at $700{ }^{\circ} \mathrm{C}$ for $2 \mathrm{~h}$, then passed along to austenite destabilization at $1000{ }^{\circ} \mathrm{C}$ during $5 \mathrm{~h}$, forced air cooled and finally tempered at $250^{\circ} \mathrm{C}$ for $2 \mathrm{~h}$, in order to increase the transformation of the austenitic matrix into a martensitic one $[2,13,15,16]$.

The samples were wet sanded in ascending order of sandpaper grit sizes: 80, 120, 220, 320, 400 and 600 meshes; after that, they were polished using 9, 3 and $1 \mu \mathrm{m}$ diamond paste. They were chemically etched with Vilella's reagent $(1 \mathrm{~g}$ picric acid $+5 \mathrm{ml}$ hydrochloric acid $+100 \mathrm{ml}$ ethanol) for $5 \mathrm{~s}$ to $20 \mathrm{~s}$ duration.

The X-ray diffraction experiments were performed using a Shimadzu XRD-7000 instrument with $\mathrm{Cu}$ $\mathrm{K} \alpha$ radiation, a step-size of $0.02^{\circ}$, scanning speed of $2^{\circ} / \mathrm{min}$ and a $2 \theta$ range of $30^{\circ}-85^{\circ}$.

The optical microscopy was conducted using an Inverted Platinum Metallographic Microscope Fortel IM713 instrument, while the scanning electron microscopy (SEM) analysis was carried out using a JSM6510LV-JEOL instrument equipped with a Thermo Scientific Ultra Dry microprobe for energy dispersive spectroscopy (EDS).

Measurements of microhardness were performed using both Wolpert and Shimadzu instruments at 400x magnification. In this test, 10 indentations were performed in each specific component of all alloys, for that a square-based diamond pyramid indenter was used with a 50g load applied for both matrix and carbides.

In terms of Rockwell-C hardness, 18 measurements for each alloy were conducted using an IGV RM401/A instrument. The carbide volume fraction (CVF) was only specified for the heat-treated samples; for these, 10 images, with 500x magnification for each alloy, were analyzed using the software Fiji Is Just Image J. A single factor ANOVA analysis was performed in Microsoft Excel with $\alpha=0.05$. 


\section{RESULTS AND DISCUSSION}

The position of the HCCI $0 \% \mathrm{Nb}$ standard alloy on the metastable liquid surface $\mathrm{Fe}-\mathrm{Cr}-\mathrm{C}$, proposed by Thorpe and Chicco [17] can be observed in Figure 1. The alloy in this image is found near the eutectic region (line $\mathrm{U} 1 \rightleftharpoons \mathrm{U} 2$ ). The solidification is initiated by the formation of proeutectic austenite $(\gamma)$ around $1300^{\circ} \mathrm{C}$ and the chemical composition of the liquid is modified towards the eutectic solidification line U1 $\rightleftharpoons \mathrm{U} 2-$ when the eutectic formation takes place [17].

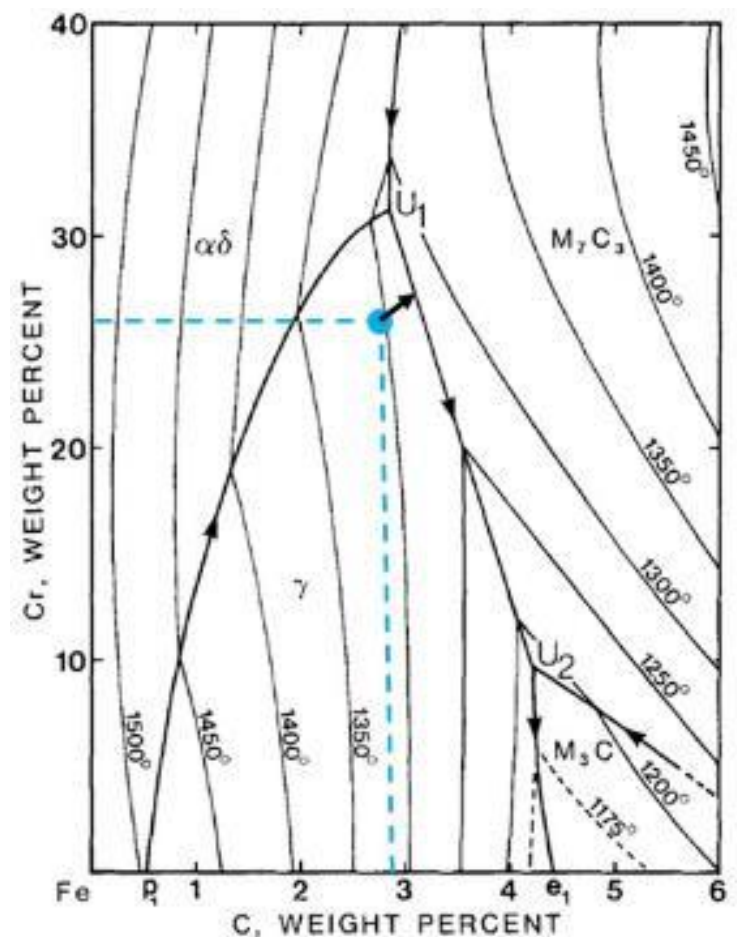

Figure 1: $26 \% \mathrm{Cr}-2.9 \% \mathrm{C}$ position on Fe-rich corner of metastable C-Cr-Fe liquidus surface [17].

The X-ray diffraction pattern presented in Figure 2 confirms the presence of austenite phases and $\mathrm{M}_{7} \mathrm{C}_{3}$ carbides, which is shown by various peaks in the standard HCCI $0 \% \mathrm{Nb}$ alloy, as well as the tested HCCI $0.5 \% \mathrm{Nb}$ and $\mathrm{HCCI} 1 \% \mathrm{Nb}$ alloys, all in as-cast conditions. Due to the proximity of peaks referent to $\mathrm{M}_{7} \mathrm{C}_{3}$ and martensite $\left(\sim 44^{\circ}\right)$, the X-ray diffraction indicates a possibility of martensite formation during the cooling phase of pieces in as-cast conditions, which is in accordance to Dogan et al. [18], who affirmed that in general, the $26 \mathrm{Cr}$ alloys are composed of an austenitic matrix and $\mathrm{M}_{7} \mathrm{C}_{3}$ carbides, with a layer of martensite surrounding the carbides. 


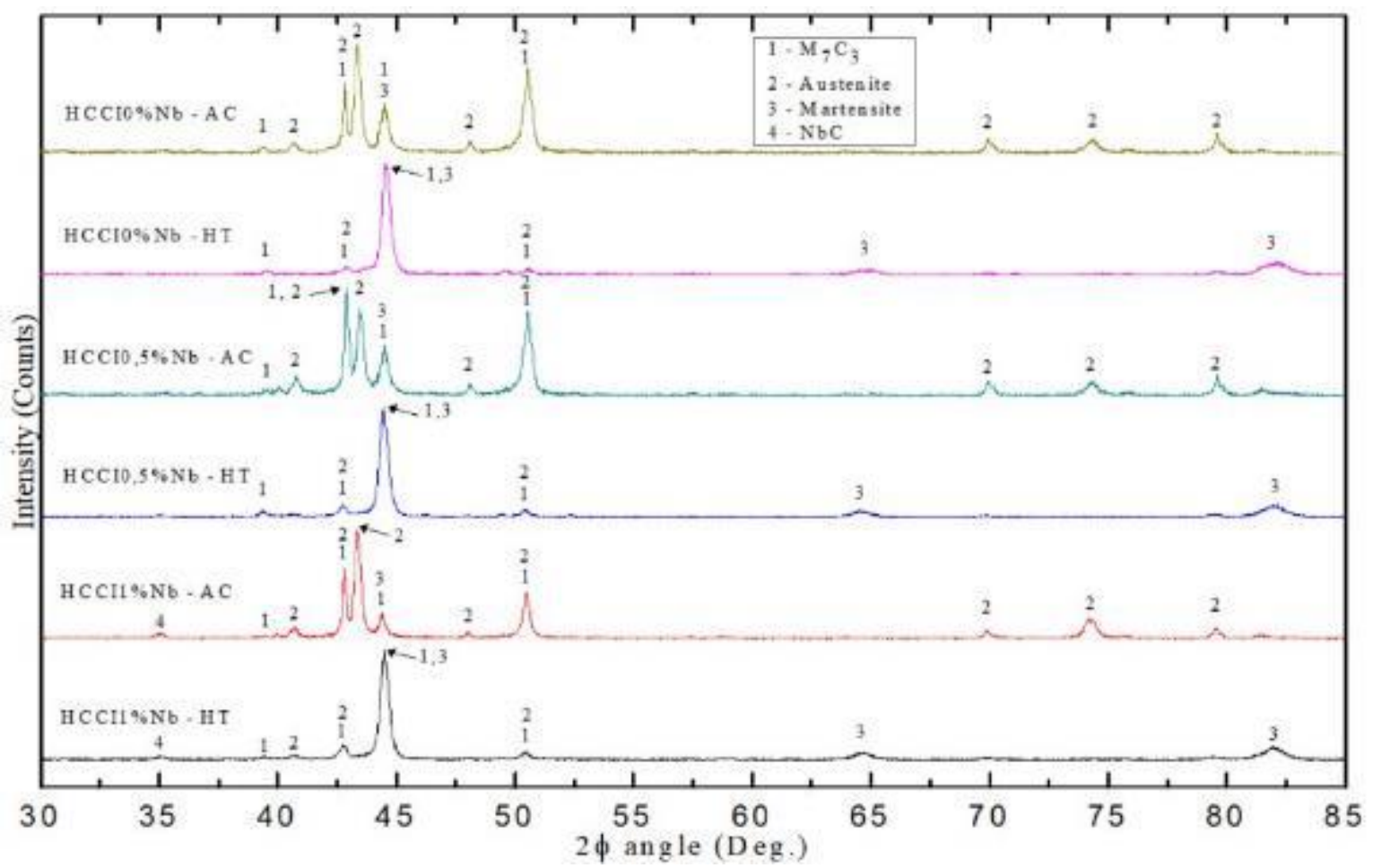

Figure 2: X-ray diffractions performed in 'as casted' and heat-treated samples.

The three alloys without heat treatment resulted in similar spectrums, from which the surging of a peak referent to $\mathrm{NbC}$ in $\mathrm{HCCI} 1 \% \mathrm{Nb}$ alloy could be highlighted. The surging of these peak was also expected for the HCCI $0.5 \% \mathrm{Nb}$ alloy; however, it could not be observed, the most likely reason is the low $\mathrm{Nb}$ content in this particular alloy. After heat treatment, the spectrums were altered in a similar manner for all three alloys, most of the austenite $(\gamma)$ peaks have disappeared, while new martensite peaks have emerged, which is a result of austenite transformation into martensite during heat treatment. However, the $41^{\circ}, 43^{\circ}$ and $50.5^{\circ}$ peaks indicate presence of retained austenite in the heat-treated alloys.

The microstructures for the alloys without heat treatment are presented in Figure 3. The HCCI $0 \% \mathrm{Nb}$ (Fig. 3a) showed a microstructure quasi-eutectic, which was composed by small fraction of proeutectic austenite and eutectic of austenite $(\gamma)+$ rod-type [18] $\mathrm{M}_{7} \mathrm{C}_{3}$ carbides morphologies identified by number 1 . In Fig. 3 (b) and (c) it was possible to observe that the addition of $\mathrm{Nb}$ and its respective increase was responsible for altering a quasi-eutectic microstructure into a hypoeutectic one through the appearing of proeutectic austenite $(\gamma)$ dendrites. This modification resulted in a eutectic morphology modification, promoting the appearing of blade-type carbides [18] $\mathrm{M}_{7} \mathrm{C}_{3}$ carbides identified by number 2, this is caused by a presence of larger fractions of proeutectic austenite, which promotes a smaller undercooling (because of the heat released by the formation of the proeutectic austenite), favoring the blade-type carbide shape formation [18]. It is possible to observe the formation of thin $\mathrm{NbC}$ agglomerates in the $0.5 \%$ and $1.0 \% \mathrm{Nb}$ alloys. 

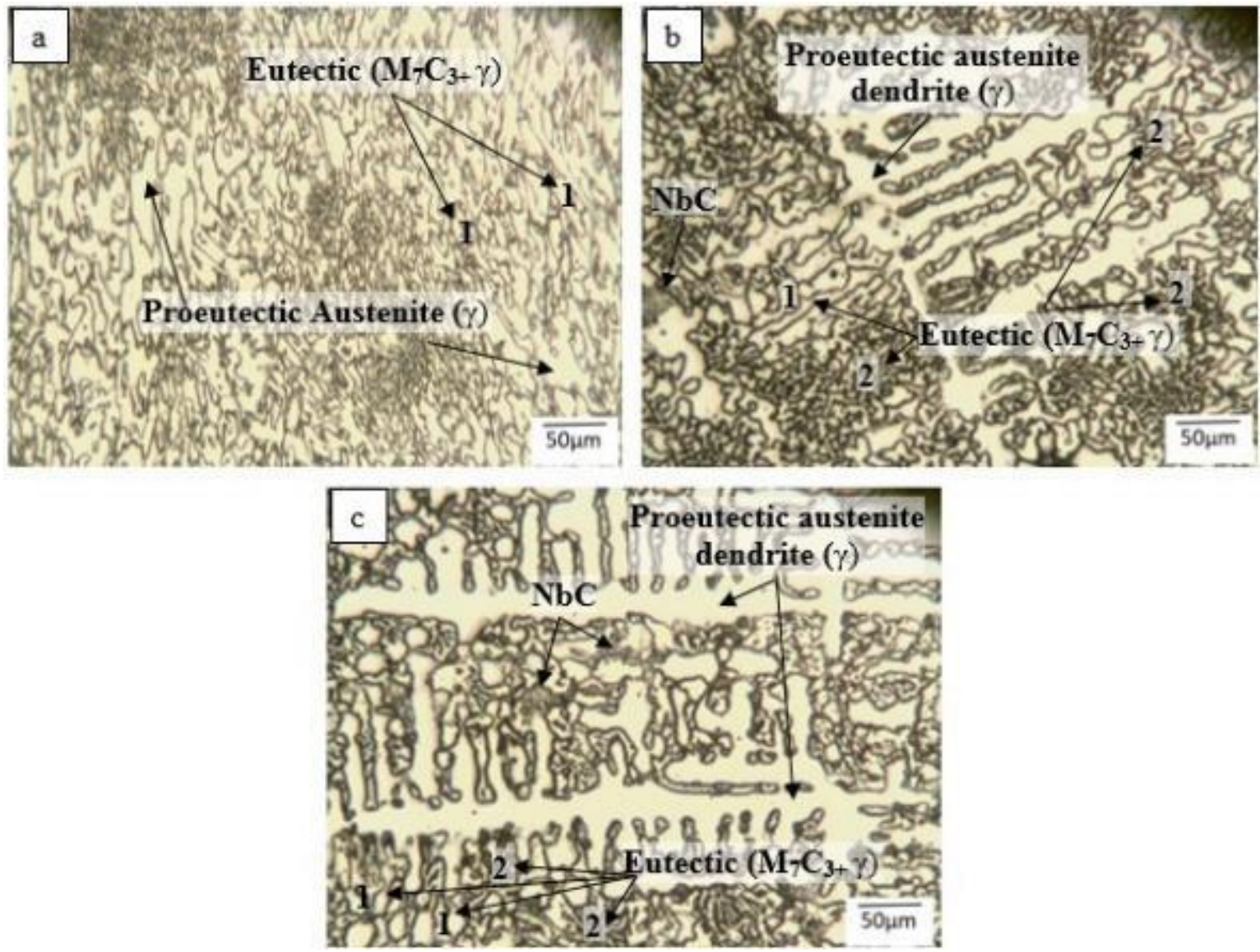

Figure 3: Optical microscopy of no heat treatment alloys (a) HCCI $0 \% \mathrm{Nb}$; (b) HCCI $0.5 \% \mathrm{Nb}$; (c) HCCI $1 \% \mathrm{Nb}$. 1: rodstype $\mathrm{M}_{7} \mathrm{C}_{3}$ carbides; 2 : blade-type $\mathrm{M}_{7} \mathrm{C}_{3}$ carbides.

The presence of austenite dendrites caused by the addition of $\mathrm{Nb}$ suggests a right-shift of the eutectic line $\mathrm{U} 1 \rightleftharpoons \mathrm{U} 2$ showed in Fig. 2 [4]. Similar microstructural changes caused by addition of Nb were observed by He-Xing et al. [4], Filipovic et al. [5]; Ibrahim; El-Hadad; Mourad [6]. In order to better evaluate the alterations caused by the heat treatment, the photomicrographs obtained via SEM and their respective chemical analysis done in heat-treated samples are shown in Figures 5, 6 and 7.

The red identifies a region rich in iron, while blue represents chromium and yellow stands for niobium. The microstructure of a quasi-eutectic morphology composed by $\mathrm{M}_{7} \mathrm{C}_{3}$ carbides, which were dispersed in a predominantly martensitic matrix + secondary carbides (SC) could be observed in Figure 4 (a). The precipitation of secondary carbides occurs in annealing and destabilization during the heat treatment. This occurs due to the depletion of elements from the saturated matrix, which results in an increase for the temperature (Ms) where the transformation of austenite into martensite occurs, enabling a maximum amount of martensite formation [19].

In the chemical mapping (Fig. $4 \mathrm{~b}$ ), it is possible to observe that $\mathrm{M}_{7} \mathrm{C}_{3}$ carbides are rich in chromium, while their matrix is predominantly composed by iron. It is also possible to notice a similar microstructure among the HCCI $0.5 \% \mathrm{Nb}$ (Figure 5) e HCCI $1 \% \mathrm{Nb}$ (Figures 6 and 7). Both alloys presented $\mathrm{M}_{7} \mathrm{C}_{3}$ carbides rich in chromium and dispersed in a martensite rich matrix + secondary carbides, but different from each other in terms of eutectic carbide fraction and precipitation of $\mathrm{NbC}$ carbides. These two alloys presented thin and agglomerated $\mathrm{NbC}$ carbides. 


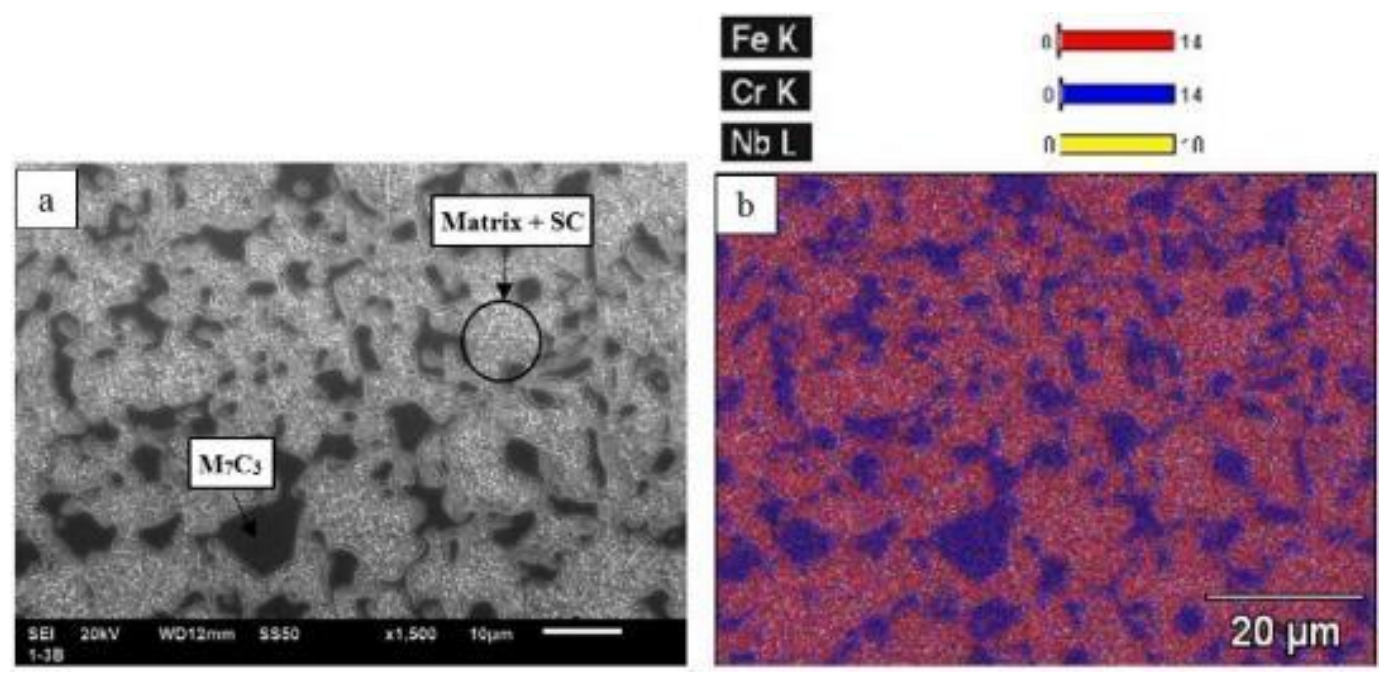

Figure 4: (a) SEM; and (b) chemical mapping of HCCI $0 \% \mathrm{Nb}$.
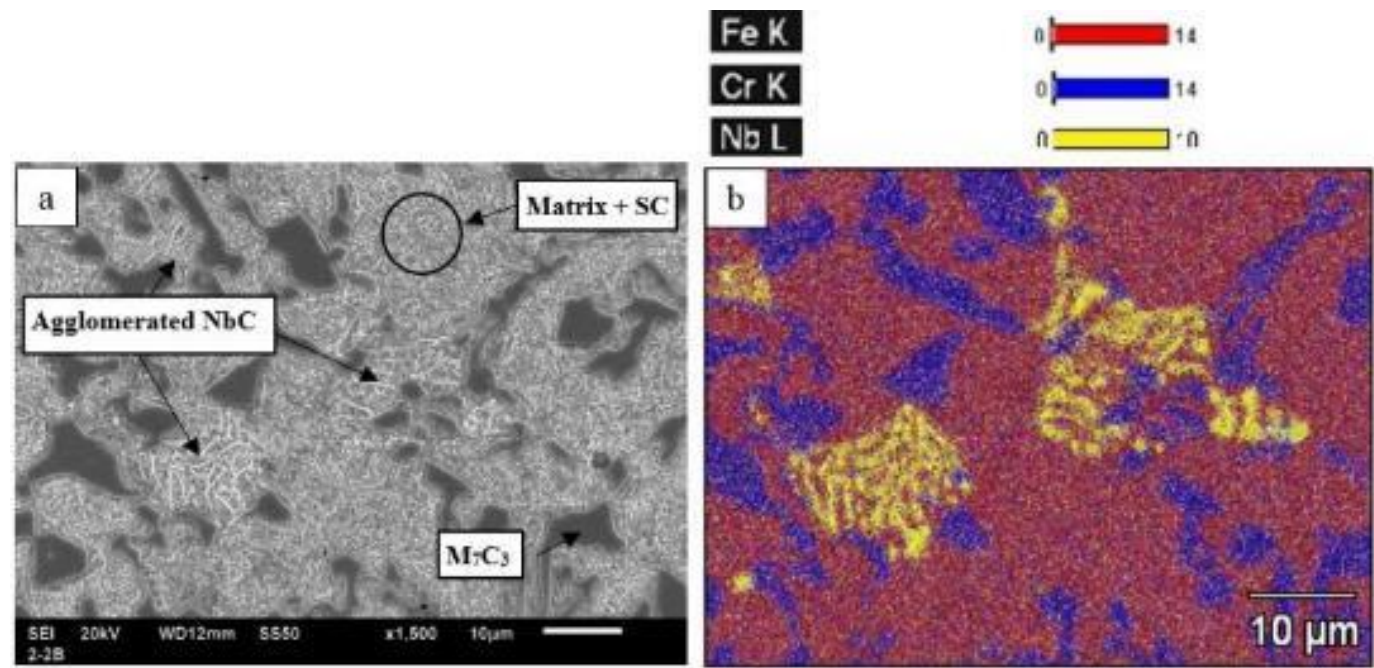

Figure 5: (a) SEM; and (b) chemical mapping of HCCI $0.5 \% \mathrm{Nb}$.

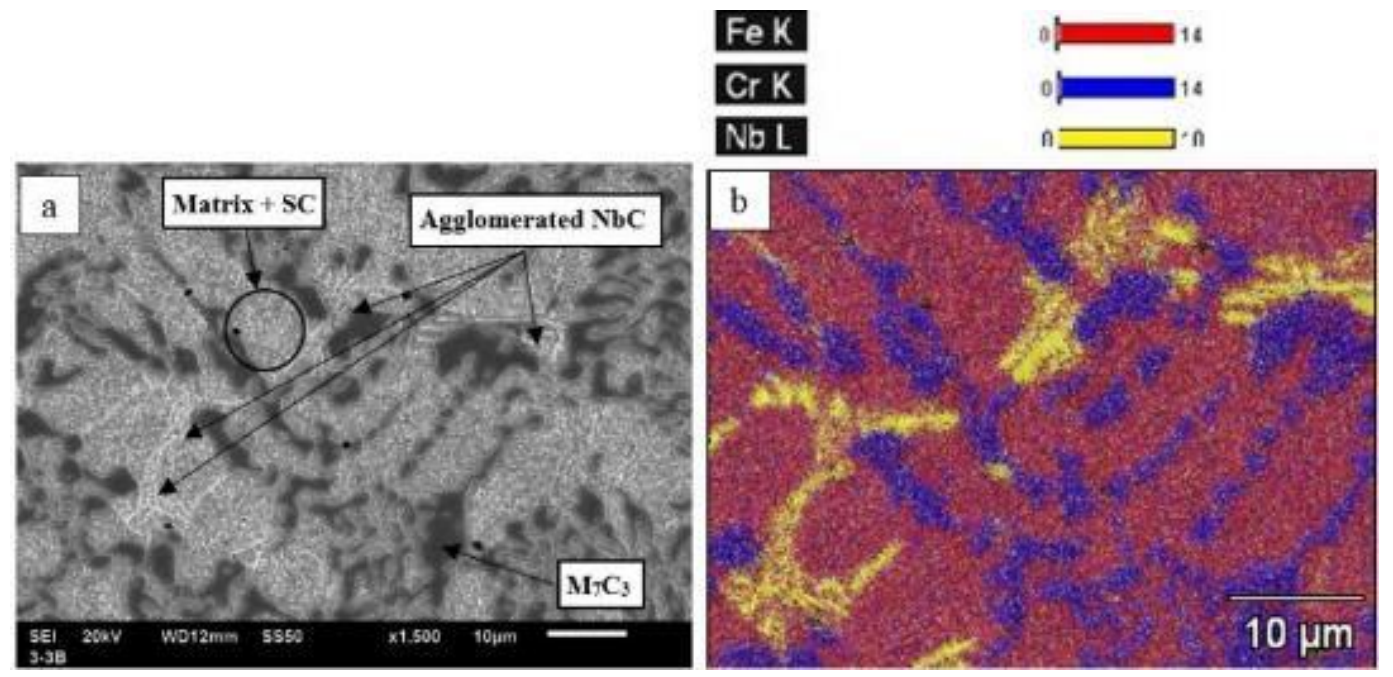

Figure 6: (a) SEM; and (b) chemical mapping of HCCI $1 \% \mathrm{Nb}$. 
The X-ray diffractions indicated presence of retained austenite in samples after heat treatment. The SEM image in Figure 7 shows the morphology of secondary carbides and presence of martensite and retained austenite. It was also possible to verify martensite in platelet forms and retained austenite in islet forms dispersed between the martensite regions.

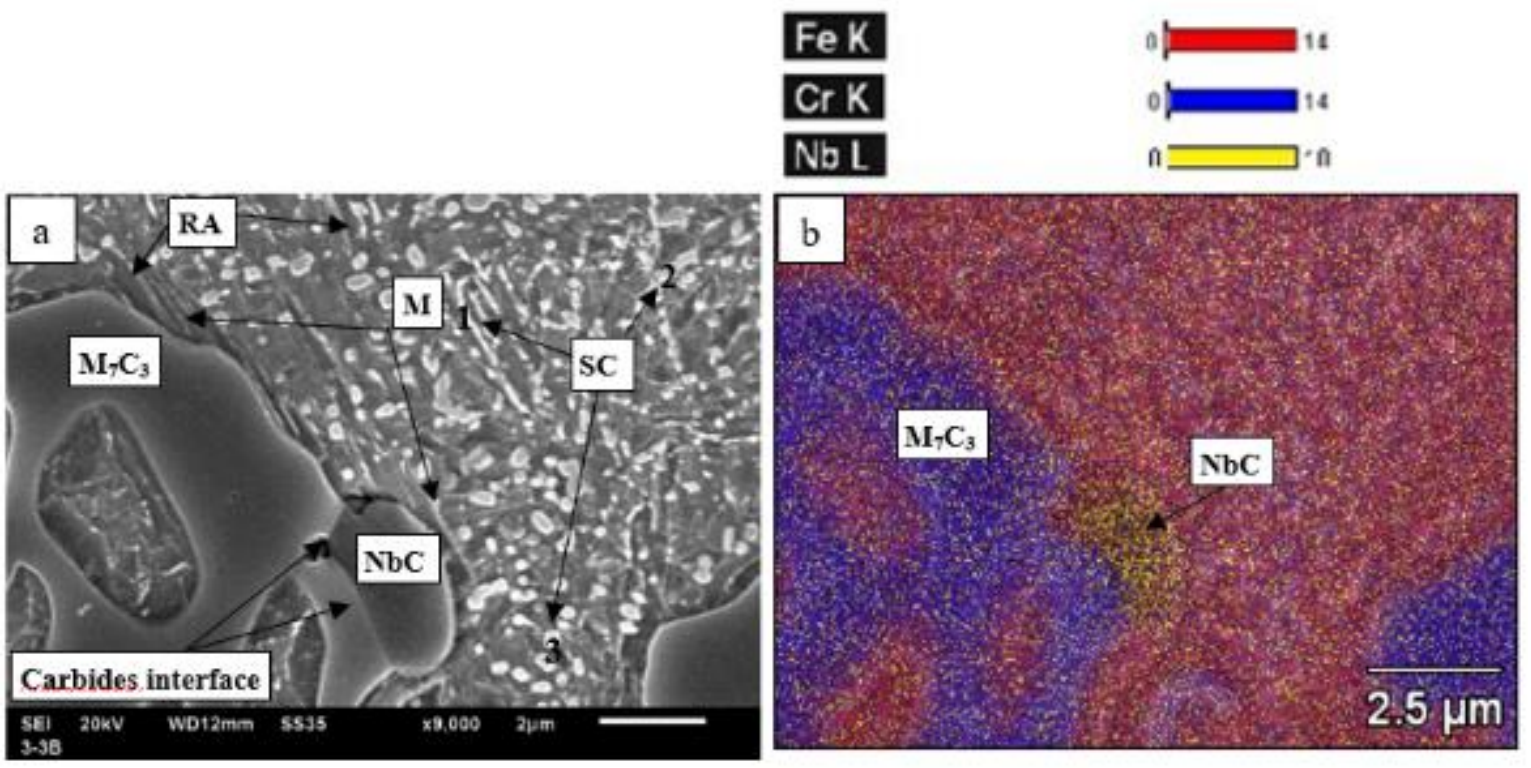

Figure 7: (a) SEM; and (b) chemical mapping of HCCI 1\% Nb.

There are three types of carbides presented in the literature: $\mathrm{M}_{23} \mathrm{C}_{6}, \mathrm{M}_{3} \mathrm{C}$ and $\mathrm{M}_{7} \mathrm{C}_{3}$ [17], [20]. However, the presence of the first two types was discarded based on the peaks shown in the X-ray diffractions and morphology comparisons to the work of Power and Laird [20]. Three distinct morphologies were observed for the secondary carbides: discrete rods, identified as number 1 in Figure 7, also plate-like shapes, identified as 2 , and rod-like particles as number 3 .

In Figure 7 (a), a $\mathrm{NbC}$ carbide is shown closed to $\mathrm{M}_{7} \mathrm{C}_{3}$ carbide rich in chromium, and is also possible to observe an interface formed between the two carbides. The Nb-rich region of the $\mathrm{NbC}$ carbide can be observed in Figure 7 (b).

In Figure 8, it is possible to notice a statistically significant reduction of CVF, which corroborates with the results and microstructural alterations observed by Fiset et al. [7], Filipovic [8] and Pacheco [12].

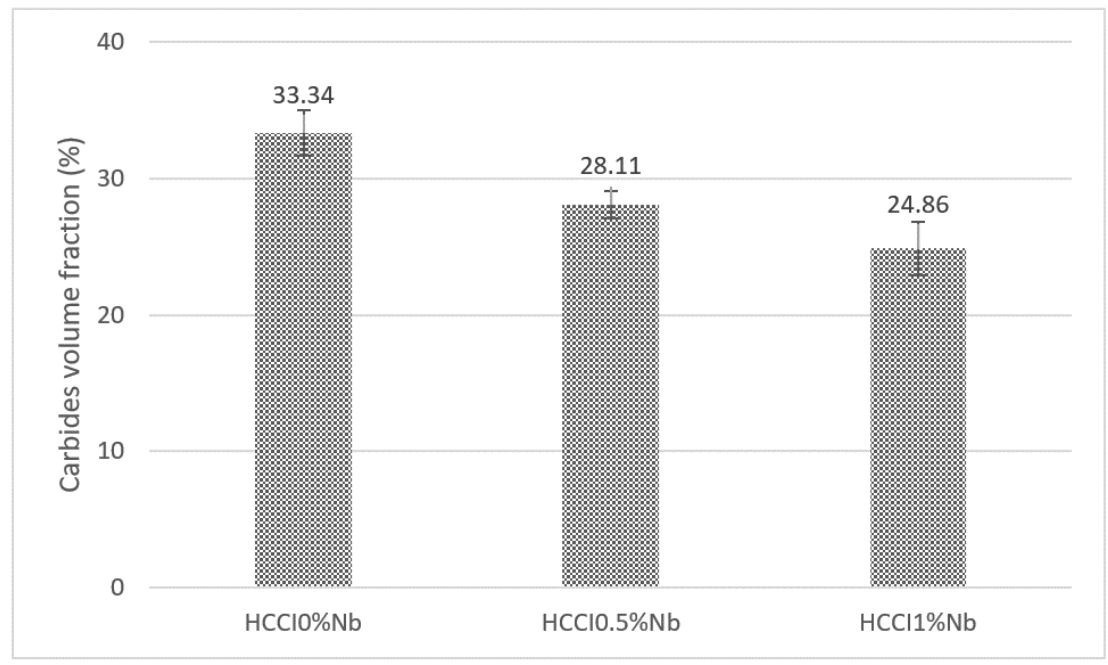

Figure 8: Carbides volume fraction. 
The morphology change, from a quasi-eutectic microstructure to a hypoeutectic one, and the CVF reduction occur because niobium is a strong carbide forming and has higher melting temperature $\left(3500^{\circ} \mathrm{C}\right)$ than the high $\mathrm{Cr}$ liquid [21]. Thus, niobium carbides precipitates in the liquid, which reduces the amount of carbon available in the matrix to form $\mathrm{M}_{7} \mathrm{C}_{3}$ carbides, and acts forming nucleation sites for austenitic dendrites, resulting in a lower CVF and a more refined microstructure [6].

Figure 9 shows the values obtained for hardness of the alloys with martensitic matrix (heat-treated) and austenitic matrix (as-cast) as a function of the CVF. The one-way ANOVA analysis is shown in Table 2, from which can be noticed that there was statistical difference for the hardness of alloys with austenitic matrix.

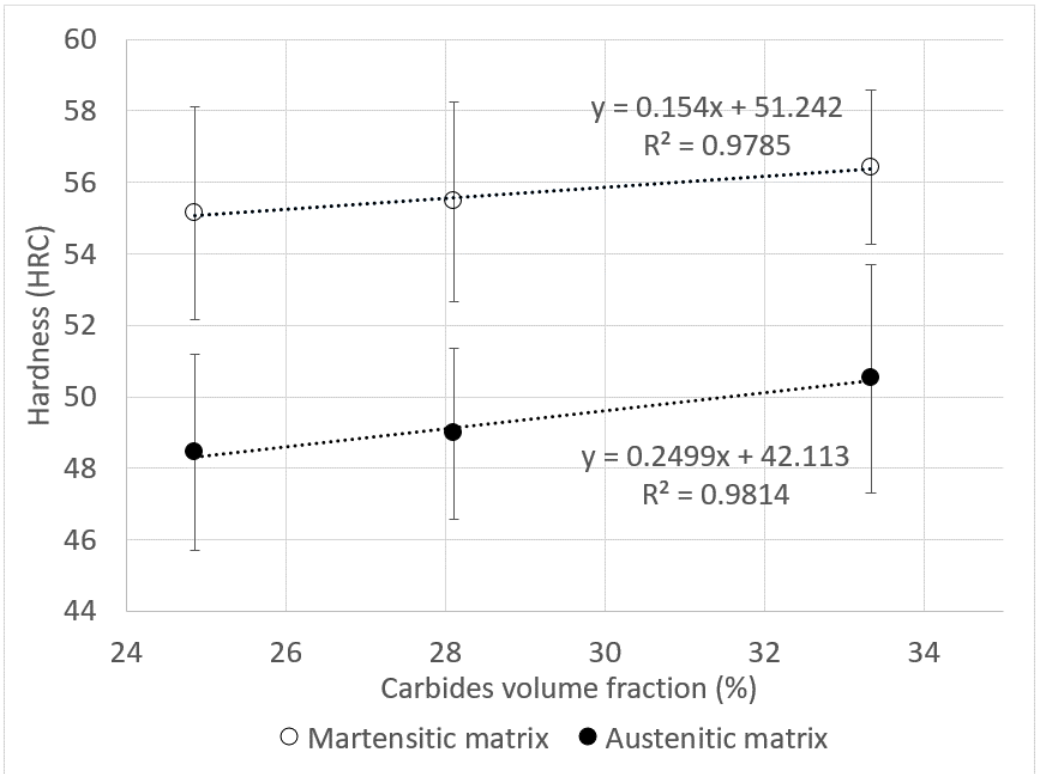

Figure 9: Alloys hardness.

Table 2: Alloys hardness variance analysis.

\begin{tabular}{llcccl}
\hline CONDITION & P-VALUE & $\boldsymbol{\alpha}$ & $\mathbf{F}$ & F $_{\text {CRITICAL }}$ & CONCLUSION \\
\cline { 1 - 5 } As-cast & 0.011 & 0.05 & 4.744 & 3.091 & Different \\
Heat-treated & 0.354 & 0.05 & 1.060 & 3.179 & Same \\
\hline
\end{tabular}

The ANOVA analysis indicates a statistical difference for at least one pair of means of alloys with austenitic matrix (for the CVF assessed). A linear regression of the data resulted in a slope of 0.2499 and a square correlation coefficient $\mathrm{R}^{2}=0.9814$, which indicated a good correlation to the actual curve.

The linear regression for hardness measurements in alloys with martensitic matrix resulted in a slope of 0.154 and $\mathrm{R}^{2}=0.9785$. However, the ANOVA analysis indicated no statistical difference in hardness as a function of CVF, for the values assessed.

The comparison between the slopes of the two regressed lines and the ANOVA indicates that hardness varied more sensibly to CVF values in alloys with austenitic matrix, when compared to martensitic ones. This behavior was also observed by the studies of Zum Gahr and Eldis [3] and Laird et al. [2].

The data obtained by Zum Gahr and Eldis [3] showed an increase in hardness as a function of CVF for alloys with austenitic matrix, same results as Dogan et al. [18] for $26 \% \mathrm{Cr}$ alloys. Values of hardness $\left(\mathrm{HV}_{50}\right)$ and CVF between 20 and $40 \%$ were extracted from the paper of Zum Gahr and Eldis [3]. The work of Dogan et al. [18] indicated a table of Brinell hardness values and the present work states its values in Rockwell-C. In order to compare these different studies, all values were converted to $\mathrm{HV}_{50}$, according to ASTM E140

[22], which resulted in Figure 10. 


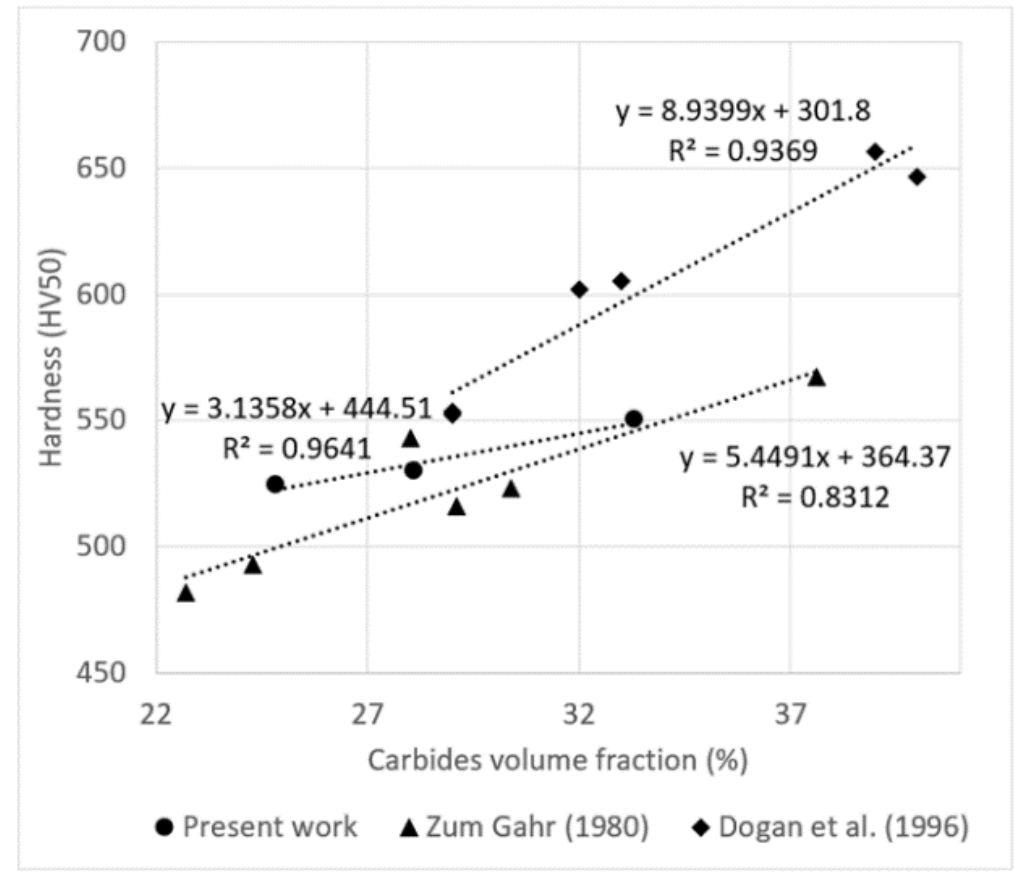

Figure 10: Comparison between hardness variations as a function of CVF in alloys with austenitic matrix obtained by the present work and also by Zum Gahr [3] e Dogan et al. [18].

These three studies indicated a good squared correlation coefficient $\left(\mathrm{R}^{2}\right)$; consequently, a strong linear correlation for the ranges assessed. It is important to note a sensible reduction in the slope $(\operatorname{tg} \theta)$ for the present work $(\operatorname{tg} \theta=3.1358)$, when compared to the lines obtained through the data extracted from Zum Gahr and Eldis [3] $(\operatorname{tg} \theta=5.4491)$ and Dogan et al. [18] $(\operatorname{tg} \theta=8.9399)$. This result indicates that an increase in niobium content, for the alloys in this present study, resulted in less sensibility variation for hardness as a function of CVF.

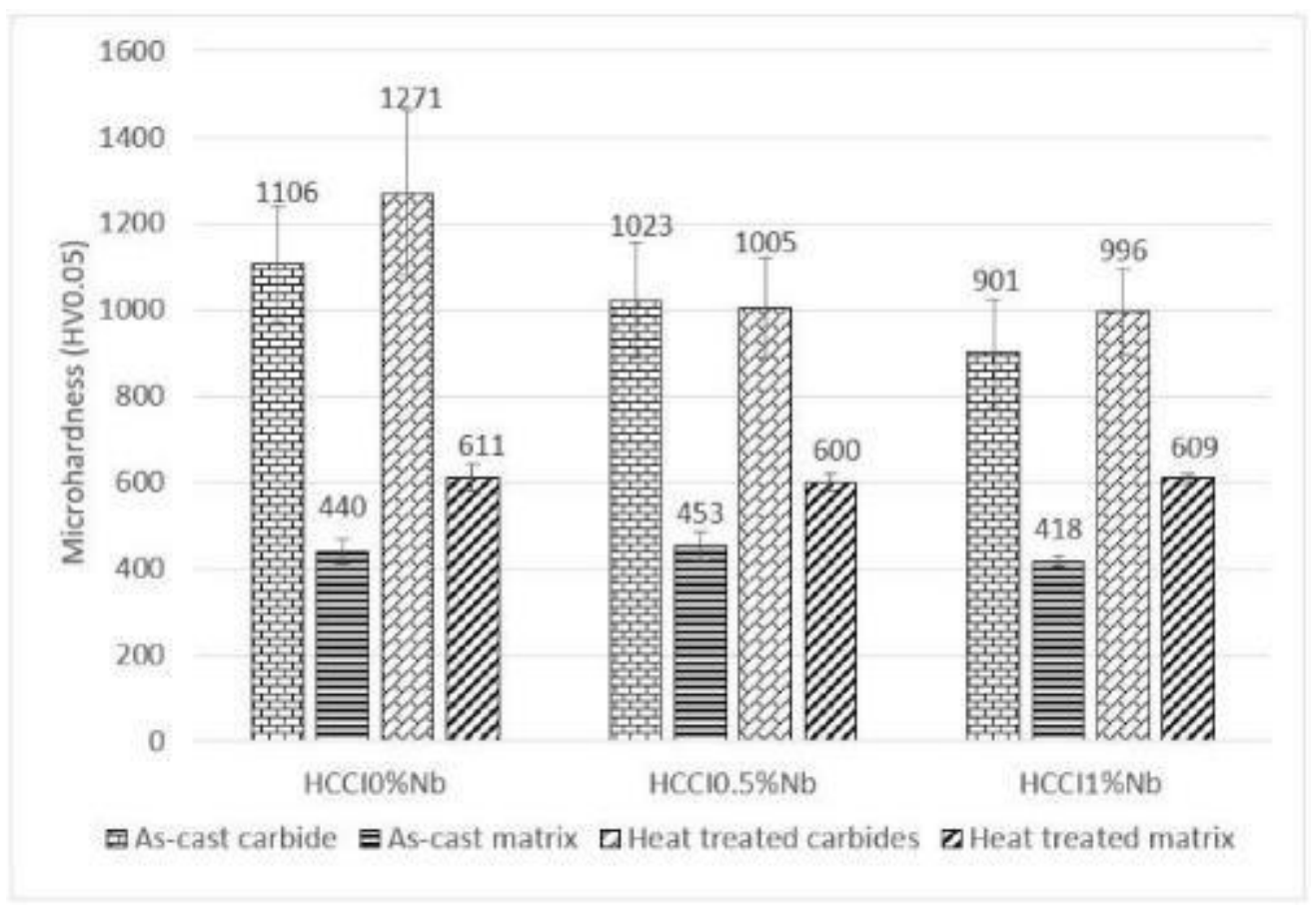

Figure 11: Alloys microhardness. 
The microhardness of matrices and carbides for the heat-treated and 'as-cast' samples are shown in Figure 11 with their respective ANOVA in Table 3. From these, it can be drawn that niobium addition was responsible for a statistical significant decrease in microhardness of carbides for both conditions. There was also variation in microhardness for the matrices under 'as-cast' condition: a $0.5 \% \mathrm{Nb}$ addition increased microhardness, but when the addition increased to $1.0 \%$, the microhardness decreased.

Table 3: ANOVA results of microhardness in alloys.

\begin{tabular}{cccccc}
\hline CONDITION & P-VALUE & $\boldsymbol{\alpha}$ & \multicolumn{1}{c}{ F } & F CRITICAL & CONCLUSION \\
\cline { 2 - 6 } & \multicolumn{5}{c}{ CARBIDE } \\
\cline { 2 - 6 } As-cast & 0.009 & 0.05 & 5.565 & 3.354 & Different \\
\cline { 2 - 6 } & \multicolumn{5}{c}{ MATRIX } \\
\cline { 2 - 6 } & 0.029 & 0.05 & 4.068 & 3.354 & Different \\
\cline { 2 - 6 } & \multicolumn{5}{c}{ CARBIDE } \\
Heat-treated & 0.000 & 0.05 & 11.233 & 3.354 & Different \\
\cline { 2 - 5 } & \multicolumn{5}{c}{ MATRIX } \\
\cline { 2 - 6 } & 0.582 & 0.05 & 0.552 & 3.354 & Same \\
\hline
\end{tabular}

Under heat treatment conditions, the addition of niobium was not responsible for statistical variations in microhardness for the matrices.

A correlation of hardness and microhardness for the heat-treated samples is show in Figure 12.

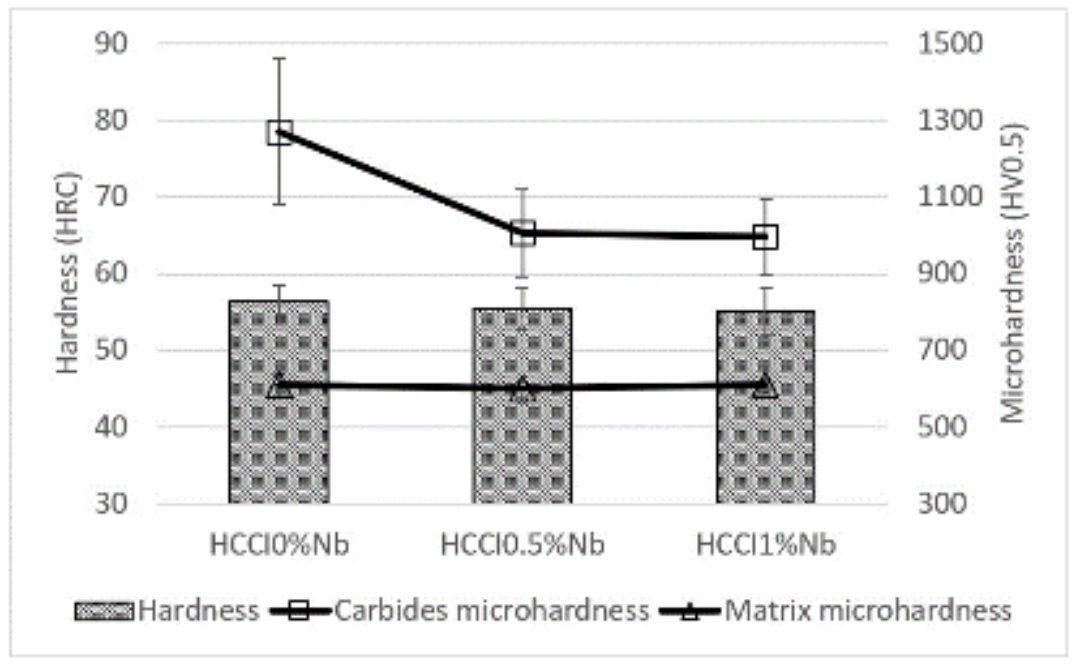

Figure 12: Heat-treated hardness and microhardness alloys.

As a result of a decrease in CVF (Fig. 8) and microhardness of carbides (Fig. 11), a lower hardness was expected for the alloys; however, this was not the case for the heat-treated alloys, as can be seen in Figures 9 and 12. This effect could be explained by a lower sensibility in hardness as a function of CVF for the alloys with martensitic matrix [2,3], and in contrast, the diminishing of this sensibility caused by the increase in niobium content as observed in the present study (Figure 10).

\section{CONCLUSIONS}

The $\mathrm{NbC}$ carbides were observed in the $0.5 \%$ and $1.0 \%$ alloys as homogeneously disperse agglomerates with thin morphology, needle shaped and hook profile.

The addition of niobium in the alloys promoted a change in its quasi-eutectic morphology into a hypoeutectic morphology; it also promoted a reduction in CVF. 
The heat treatment was responsible for altering the predominantly austenitic matrix into a predominantly martensitic matrix with secondary $\mathrm{M}_{7} \mathrm{C}_{3}$ carbides and retained austenite.

In the 'as-cast' alloys, the addition of niobium caused an increase in microhardness of matrices for the $0.5 \% \mathrm{Nb}$ alloy, but a reduction for the $1.0 \% \mathrm{Nb}$ alloy. There was reduction in microhardness of carbides for both $\mathrm{Nb}$ contents. As for the heat-treated alloys, there was reduction in microhardness of carbides, while no significant changes were observed for matrix microhardness.

The hardness of alloys with predominantly austenitic matrix were showed to be more susceptible to variations in CVF when compared to alloys with predominantly martensitic matrix.

The comparison of the present study with the literature $[3,18]$ indicates that hardness sensibility, as a function of $\mathrm{CVF}$, decreased with a $\mathrm{Nb}$ content increase in the alloys.

\section{ACKNOWLEDGMENTS}

Thanks FINEP for the financing of equipment (01.09.0397.00 - CTINFRA 2008, 01.10.0794.00 CTINFRA 2009), FAPEMIG and the Federal Center of Technological Education of Minas Gerais for the master's degree scholarship.

\section{BIBLIOGRAPHY}

[1] ZUM GAHR, K.-H., Microstructure and wear of materials, v. 10, Elsevier, 1987.

[2] LAIRD, G., GUNDLACH, R., ROHRIG, K., Abrasion-resistant cast iron handbook. Schaumburg, IL: American Foundry Society, 2000.

[3] ZUM GAHR, K.-H., ELDIS, G. T., “Abrasive wear of white cast irons”, Wear, v. 64, n 1, pp. 175-194, out. 1980 .

[4] HE-XING, C., ZHE-CHUAN, C., JIN-CAI, L., et al., "Effect of niobium on wear resistance of $15 \% \mathrm{Cr}$ white cast iron", Wear, v. 166, n 2, pp. 197-201, jul. 1993.

[5] FILIPOVIC, M., KAMBEROVIC, Z., KORAC, M., et al., "Effect of Niobium and Vanadium additions on the as-cast microstructure and properties of hypoeutectic $\mathrm{Fe}-\mathrm{Cr}-\mathrm{C}$ alloy”, ISIJ Int., v. 53, n 12, pp. 2160 2166, dez. 2013.

[6] IBRAHIM, M. M., EL-HADAD, S., MOURAD, M., "Enhancement of wear resistance and impact toughness of as cast hypoeutectic high chromium cast iron using niobium", International Journal of Cast Metals Research, pp. 1-8, 2017.

[7] FISET, M., PEEV, K., RADULOVIC, M., "The influence of niobium on fracture toughness and abrasion resistance in high-chromium white cast irons", Journal of Materials Science Letters, pp. 615-617, 1993.

[8] FILIPOVIC, M., KAMBEROVIC, K., KORAC, M., et al., "Microstructure and mechanical properties of $\mathrm{Fe}-\mathrm{Cr}-\mathrm{C}-\mathrm{Nb}$ white cast irons", Materials and Design, v. 47, pp. 41-48, 2013.

[9] GUESSER, W. L., COSTA, P. H. C., PIESKE, A., "Niobio em ferros fundidos brancos ligados ao cromo para aplicações em desgaste abrasivo", Metalurgia ABM, v. 45, n. 381, pp. 768-776, 1989.

[10] PENAGOS, J. J., ONO, F., ALBERTIN, E., SINATORA, A., "Structure refinement effect on two and three-body abrasion resistance of high chromium cast irons", Wear, v. 340, n. 341, pp. 19-24, 2015.

[11] CRUZ, E. B., FERREIRA NETO, J. B., SILVA, R. C. S. C., "Dissolução de ferro-nióbio em ferro fundido cinzento", in 54 Congresso Anual ABM, São Paulo, 1999, pp. 371-382.

[12] PACHECO, D. A., GODOY, G. C. D., OLIVEIRA, C. G., MOSQUEIRO, L., "Efeito da adição de Nb na microestrutura de ferro fundido branco alto cromo hipereutético", apresentado em Anais do $72^{\circ}$ Congresso Anual da ABM, São Paulo, 2018.

[13] PENAGOS, J. J., "Efeito do refinamento da microestrutura e da adição de nióbio na resistência ao desgaste abrasivo de ferros fundidos de alto cromo.", Tese (Doutorado Ciências), Universidade de São Paulo, São Paulo, 2016.

[14] MELO, I. N. R., GUIMARÃES, R. P., PINHEIRO, I. P., "Dissolução de ferro-nióbio em pó pelo processo de simples adição em ferro fundido branco com alto teor de cromo", in Conference: $48^{\circ}$ Seminário de Aciaria, Fundição e Metalurgia de Não-Ferrosos, São Paulo, 2017, pp. 524-531.

[15] ORTEGA, P. C., BERNARDINI, P. A. N., FREDEL, M. C., et al., "Wear resistance of high chromium white cast iron for coal grinding rolls", Revista Facultad de Ingeniería Universidad de Antioquia, n. 76, pp. 
134-142, set. 2015.

[16] TABRETT, C. P., SARE, I. R., GHOMASHCHI, M. R., "Microstructure-property relationships in high chromium white iron alloys", International Materials Reviews, v. 41, pp. 59-82, jan. 1996.

[17] THORPE, W. R., CHICCO, B.,"The Fe-rich corner of the metastable C-Cr-Fe liquidus surface”, MTA, v. 16, n 9, pp. 1541-1549, set. 1985.

[18] DOĞAN, ö. N., HAWK, J. A., LAIRD, G., "Solidification structure and abrasion resistance of high chromium white irons", Metallurgical and Materials Transactions A, v. 28, n. 6, pp. 1315-1328, jun. 1997.

[19] ORTEGA, P. C., BERNARDINI, P. A. N. TORRES, L. A., "Otimização do tratamento térmico de desestabilização do ferro fundido branco de alto cromo classe II D usado em moinhos de carvão de usinas termelétricas”, in Anais CIMM, Bogotá, 2006.

[20] POWELL, G. L. F., e LAIRD, G.,"Structure, nucleation, growth and morphology of secondary carbides in high chromium and Cr-Ni white cast irons”, Journal of materials science, v. 27, n. 1, pp. 29-35, 1992.

[21] SILVA, R. C. S. C., TAKANO, C., GUIMARÃES, J. R. C., et al., "Aspectos fundamentais da dissolução de ferro-nióbio em ferro fundido", in $57^{\circ}$ Congresso anual da ABM - Internacional, São Paulo, 2002, pp. 485-497.

[22] American Society for Testing and Materials, "ASTM E140 - 12b - Standard Hardness Conversion Tables for Metals Relationship Among Brinell Hardness, Vickers Hardness, Rockwell Hardness, Superficial Hardness, Knoop Hardness, Scleroscope Hardness, and Leeb Hardness”, West Conshohocken, PA, 2013.

\section{ORCID}

Ismael Nogueira Rabelo de Melo Anderson Edson da Silva Leonardo Roberto da Silva Ivete Peixoto Pinheiro https://orcid.org/0000-0003-3125-3687

https://orcid.org/0000-0001-9982-0110

https://orcid.org/0000-0001-6043-7931

https://orcid.org/0000-0001-5411-4052 